\title{
An Empirical Investigation of the Twin Deficits Hypothesis in Nigeria: Evidence from Cointegration Techniques
}

Nurudeen $\mathrm{Abu}^{1}$ and Awadh Ahmed Mohammed Gamal ${ }^{2}$

ABSTRACT

\begin{abstract}
Nigeria has not been able to generate adequate revenue to match her expenditure over the years. It is not surprising therefore, that the country frequently operates deficit budget with its negative consequences on the current account balance. This study investigates the twin deficits hypothesis (that is, budget deficits and current account deficits relationship) for Nigeria over the 19812017 period using the Autoregressive Distributed Lag (ARDL) and Dynamic Ordinary Least Squares (DOLS) estimation techniques. The result of the cointegration test indicates that there is a long-run relationship between budget deficits and current account deficits (along with oil prices and interest rate). The estimation results show that increases in budget deficits lead to increases in current account deficits in Nigeria in the short-run and the long-run. This finding validates the Keynesian assertion, but refutes the Ricardian Equivalence Hypothesis with respect to the relationship between the two deficits in Nigeria. The result of causality test using the Toda and Yamamoto (1995) approach illustrates the existence of a one-way causality from current account deficits to budget deficits. Based on this empirical evidence, this study recommends policies to reduce both deficits
\end{abstract}

KEY WORDS: Current account deficits, Budget deficits, Twin deficits, Cointegration techniques, Nigeria

JEL Classification: E61, E62, F11.

UUmaru Musa Yar'adua University, Nigeria

${ }^{2}$ Universiti Pendidikan Sultan Idris, Malaysia

\section{Introduction}

The relationship between budget deficits and current account deficits (otherwise known as the twin deficits hypothesis) has been studied extensively by researchers over the years. The widening current account deficits and fiscal deficits in the United States in the 1980s increased the awareness of the twin deficits phenomenon. The twin deficits hypothesis asserts that budget deficits is the major cause of current account deficits. Thus, in the Keynesian absorption theory, increases in budget deficits raise domestic absorption including imports, leading to a worsening current account posi-

Correspondence concerning this article should be addressed to: Abu Nurudeen, Umaru Musa Yar'adua University, PMB. 2218, Katsina, Nigeria.. E-mail: abu.nurudeen@yahoo.com tion (Hatemi-J \& Shukur, 2002). Also, in the MundellFleming framework, rising budget deficits leads to higher rates of interest, causing an increase in capital inflows and exchange rate appreciation, and ultimately current account deterioration (Baharumshah, Lau \& Khalid, 2006; Katircioglu, Fethi \& Fethi, 2009).

However, the Ricardian Equivalence Hypothesis (REH) rejects the claim that budget deficits leads to current account deficits. The view of this school is that government tax cuts in the current period are future tax liabilities that will be imposed on consumers to enable the government repay its debt. Given this, consumers do not consider themselves wealthier following government's expansionary fiscal policy. Therefore, the demand for both domestically produced goods and imports will not increase to the extent that the current 
account will deteriorate.

Empirical studies on the twin deficits hypothesis have reported mixed findings. For example, studies by Bachman (1992), Ahmed and Ansari (1994), Vamvoukas (1999), Leachman and Francis (2002), Chin and Prasad (2003), Pattichis (2004), Baharumshah and Lau (2007), Bluedorn and Leigh (2011), including Trachanas and Katrakilidis (2013) confirmed that there is a connection between the two deficits, and budget deficits causes/affects current account balance. On the other hand, studies by Enders and Lee (1990), Alse and Bahmani-Oskooee (1992), Basu and Datta (2005), Aristovnik and Djurić (2010) failed to establish any link between the two deficits, thus, lending support to the REH.

Nigeria like many economies is not immuned from the twin deficits problem. As an economy that depends largely on oil exports for government (fiscal) revenue and substantial contribution to the gross domestic product (GDP), Nigeria is exposed to vagaries in oil prices in the international markets. Thus, changes in oil prices affect government revenue generation capacity in the face of rising expenditure (occasioned by increasing demand for socio-economic infrastructure, among other things, by the teeming population). Consequently, shortfalls in government revenue result in budget deficits, with its attendant effects on the current account balance.

Since the 1980s, Nigeria has being making efforts to restructure its economy with a view to reducing the dominant influence of the government or public sector in economic activity. To this end, the Structural Adjustment Programme (SAP) was introduced in the early 1980s. It was expected that a reduction in government dominance in the economy will reduce fiscal deficits and overall balance of payment disequilibrium, among other things. Unfortunately, not much has been achieved as persistent budget deficits or imbalances remain a serious concern in Nigeria.

Figure 1 shows the plots of overall current account balance and budget balance. The information therein illustrates that Nigeria's overall budget balance as a percentage of GDP (BUD) was negative during the 1981-2017 period, except in 2000-2001, 2004-2008, 2011 and 2017. This implies that Nigeria has been operating deficit budgeting, an indication that govern-

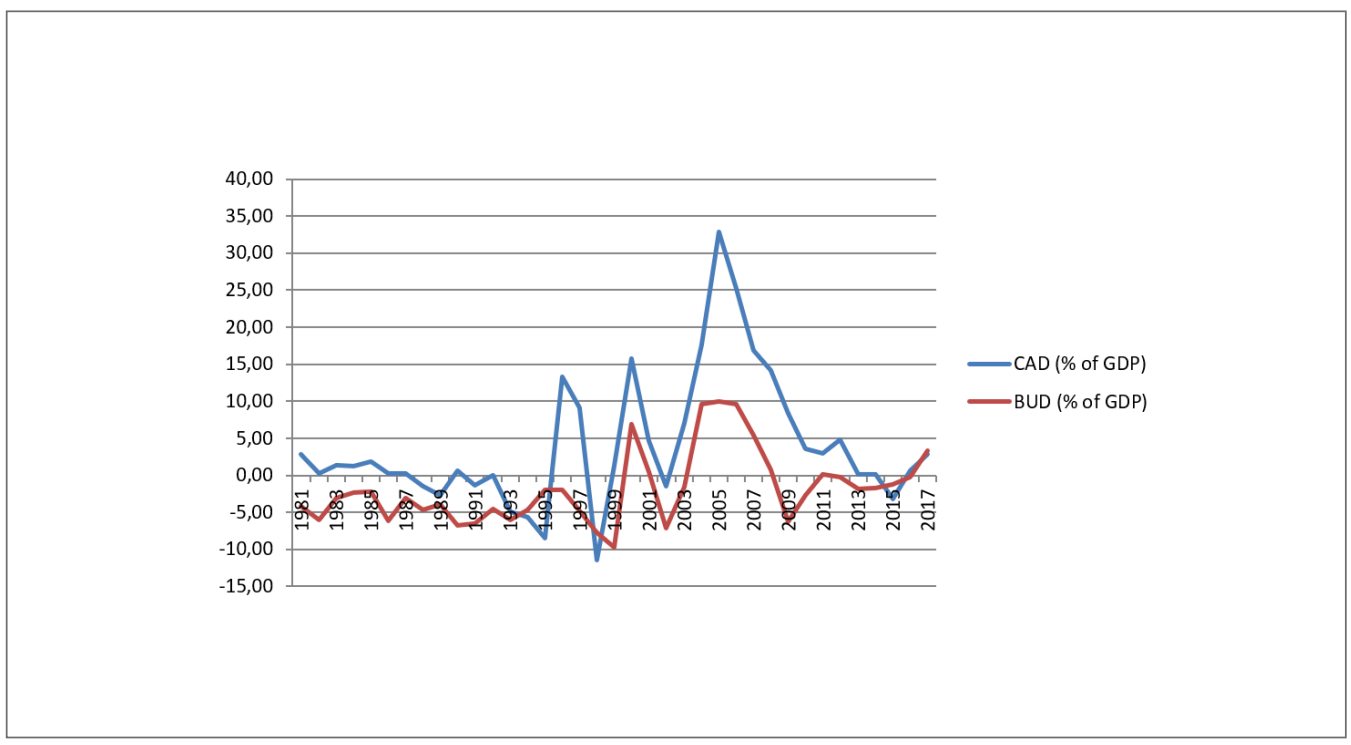

Figure 1. Plots of Nigeria's current account deficits and budget deficits based on the data collected from the Central Bank of Nigeria. 
ment revenue has often been less than government expenditure. On the other hand, the the current account balance as a percentage of GDP (CAD) was surplus in some years and deficit in others including 1988-1989, 1991, 1993-1995, 1998, 2002, and 2015.

Given the behaviour of these two economic indicators, it is not clear if budget deficits is responsible for the current account imbalance during the period under review. Therefore, it is important to embark on an empirical investigation to ascertain the connection between these variables. However, researchers have not given adequate attention to the twin deficits issue in Nigeria as the literature suggests. Interestingly, Onafowora and Owoye (2006) studied the twin deficits phenomenon in Nigeria during the 1970-2001 period using the conventional cointegration techniques of Johansen (1988) and Johansen and Juselius (1990). The results of the authors' analysis suggest that budget deficits has both short-run and long-run positive effects on trade deficits, and causality runs from trade (current account) deficits to budget deficits.

Although the efforts of Onafowora and Owoye (2006) deserve some commendations, their study did not consider important issues which the present study attempt to address. First, the authors did not consider oil prices as a potential (or an important) determinant of current account deficits. Abu (2017) argued that since the Nigerian economy and its government depend largely on oil export revenues, changing oil prices tend to affect overall economic performance. Thus, given that the current account is a component of the macroeconomy, changes in oil prices are expected to influence the current account balance or position. In fact, authors have emphasized the role of oil prices (or oil trading) in current account balance/position (see Bayraktar, Egri \& Yildiz, 2016; Besel, 2017; Huntington, 2015; Musau \& Veka, 2018; Özata, 2014).

Secondly, it has been suggested that the conventional cointegration methods employed by Onafowora and Owoye (2006) in analyzing their data (which is small sample) including the residual-based technique (Engle \& Granger, 1987) and Maximum likelihood test (Johansen, 1988; 1991; Johansen \& Juselius, 1990) are less efficient compared to the ARDL and DOLS techniques used in the present study when dealing with small samples (see Abu, 2017, 2019; Abu \& Staniewski, 2019; Ozturk \& Acaravci, 2010; 2011). In addition, these techniques correct potential simultaneity bias and/or endogeneity among regressors (see Alhassan \& Fiador, 2014; Montalvo, 1995; Narayan \& Narayan, 2004; Singh, 2015). Moreover, the standard Granger causality test used by Onafowora and Owoye (2006) to determine the direction of causality between the two deficits is more sensitive to problems with residuals in finite/small samples compared to the Toda-Yamamoto causality test employed in the present study (see Toda \& Yamamoto, 1995; Zapata \& Rambaldi, 1997). Furthermore, using these estimation techniques provides an avenue for the comparison as well as ascertaining the consistency and robustness of the results.

The estimation results demonstrate that budget deficits has a positive and significant effect on current account deficits in the short-run and the long-run in Nigeria. This outcome is consistent with the finding by Onafowora and Owoye (2006). Also, oil prices and interest rate do have a negative and significant effect on current account deficits in the long-run. In addition, there is a one-way causal relationship between the two deficits, running from current account deficits to budget deficits. This finding lends support to the one reported by Onafowora and Owoye (2006) that trade (current account) deficits causes budget deficits in Nigeria. It is also in line with the study that employed the Toda and Yamamoto (1995) causality test and discovered that current account deficits causes budget deficits (see Kouassi, Mougoué \& Kymn, 2004).

The main objective of this study is to examine the validity of the twin deficits hypothesis in Nigeria. The remainder of this paper is organized as follows. Section two is the literature review on the twin deficits, while section three is for theoretical framework and the model. Methodology and data are taken up in section four, while section five is for results and discussion. Section six concludes the paper.

\section{Review of Empirical Literature on the Twin Deficits}

Although there is a considerable amount of empirical studies on the twin deficits hypothesis, little has been done to examine the issue in Nigeria. In addition, early empirical studies on the twin deficits hypothesis mostly focused on the United States where the awareness on the issue kick-started (for instance, see Alse \& Bahmani-Oskooee, 1992; Arora \& Dua, 1993; 
Bachman, 1992; Rosensweig \& Tallman, 1993). Most of these studies including Tang (2015) and Grier and Ye (2009) confirmed that budget deficits contributes to current account deficits in the United States. In the same vein, researchers have investigated the connection between the two deficits in developed countries such as Canada, the Group of Seven (G7), the Organization for Economic Cooperation and Development (OECD) and European countries, using various estimation methods (see Ahmed \& Ansari, 1994; Aslan, Buyrukoglu, Oz \& Nazlioglu, 2014; Bluedorn \& Leigh, 2011; Cavdar \& Aydin, 2015; Daly \& Siddiki, 2009; Forte \& Magazzino, 2013; Piersanti, 2000; Salvatore, 2006; Xie \& Chen, 2014). The results of these studies validate the twin deficits hypothesis.

On the other hand, a number of studies have looked at this relationship at individual developing economy level including Brazil, Egypt, Greece, India,
Pakistan and Turkey (see Idil, 2010; Islam, 1998; Kalou \& Paleologou, 2012; Kiran, 2011; Kumar, 2016; Lau \& Baharumshah, 2004; Marinheiro, 2008; Mukhtar, Zakaria \& Ahmed, 2007; Şen, Senturk, Sancar \& Akbas, 2014; Ucal \& Bolukbas, 2013; Vamvoukas, 1999). Almost all of these studies confirmed the existence of the twin deficits phenomenon in the respective countries. The twin deficits hypothesis has also been examined in cross country studies, focusing on either a group of developing countries or regions. Examples include African countries (Ahmad, Aworinde \& Martin, 2015; Aloryito, Senadza \& Nketiah-Amponsah, 2016), Asian countries (Lau, Mansor \& Puah, 2010), Southeast Asian countries (Anoruo \& Ramchander, 1998), ASEAN countries (Baharumshah et al., 2006), SEACEN countries (Lau \& Baharumshah, 2006), Central and Eastern European countries (Tosun, Iyidogan \& Telatar, 2014) and

Table 1. A Summary of Empirical Literature Review on Twin Deficits

\begin{tabular}{|c|c|c|c|c|}
\hline Author(s) & Country(ies) & Period & Method/Model & Findings \\
\hline $\begin{array}{l}\text { Khalid and Guan } \\
\text { (1999) }\end{array}$ & Cross country & $\begin{array}{l}\text { Varying time pe- } \\
\text { riods }\end{array}$ & $\begin{array}{l}\text { Cointegration } \\
\text { analysis }\end{array}$ & $\begin{array}{l}\text { Budget deficits granger causes cur- } \\
\text { rent account deficits in some coun- } \\
\text { tries, while the reverse is the case in } \\
\text { others. }\end{array}$ \\
\hline Aristovnik (2008) & Cross country & $1992-2003$ & $\begin{array}{l}\text { Panel regression } \\
\text { techniques }\end{array}$ & $\begin{array}{l}\text { Budget deficits leads to current ac- } \\
\text { count deficits. }\end{array}$ \\
\hline $\begin{array}{l}\text { Ahmad et al. } \\
\text { (2015) }\end{array}$ & African countries & $1980-2009$ & $\begin{array}{l}\text { Threshold coin- } \\
\text { tegration }\end{array}$ & $\begin{array}{l}\text { There is a positive long-run rela- } \\
\text { tionship between current account } \\
\text { deficit and fiscal deficit is some } \\
\text { countries, while a negative long-run } \\
\text { association exist in others. }\end{array}$ \\
\hline $\begin{array}{l}\text { Bollano and } \\
\text { Ibrahimaj (2015) }\end{array}$ & CEE countries & $\begin{array}{l}\text { 2005-2014 Qua- } \\
\text { terly data }\end{array}$ & $\begin{array}{l}\text { Panel VAR with } \\
\text { FE }\end{array}$ & $\begin{array}{l}\text { A deterioration in fiscal balance } \\
\text { leads to a worsening current ac- } \\
\text { count position. }\end{array}$ \\
\hline
\end{tabular}


Table 1. A Summary of Empirical Literature Review on Twin Deficits (Continued)

\begin{tabular}{|c|c|c|c|c|}
\hline Author(s) & Country(ies) & Period & Method/Model & Findings \\
\hline $\begin{array}{l}\text { Mumtaz } \\
\text { and Munir } \\
\text { (2016) }\end{array}$ & $\begin{array}{l}\text { South Asian } \\
\text { countries }\end{array}$ & 1981-2014 & $\begin{array}{l}\text { ARDL bounds } \\
\text { testing }\end{array}$ & $\begin{array}{l}\text { Absence of twin deficits phenome- } \\
\text { non in most of the countries studied. }\end{array}$ \\
\hline $\begin{array}{l}\text { Nadenichek } \\
\text { (2016) }\end{array}$ & Cross country & $1970-2013$ & $\begin{array}{l}\text { Regression } \\
\text { analysis }\end{array}$ & $\begin{array}{l}\text { Persistent budget deficits leads to } \\
\text { persistent trade deficits. }\end{array}$ \\
\hline $\begin{array}{l}\text { Paparas } \\
\text { et al. (2016) }\end{array}$ & Greece & $1960-2014$ & $\begin{array}{l}\text { Cointegration } \\
\text { and causality test }\end{array}$ & $\begin{array}{l}\text { Budget deficits Granger causes cur- } \\
\text { rent account deficits. }\end{array}$ \\
\hline $\begin{array}{l}\text { Aloryito } \\
\text { et al. (2016) }\end{array}$ & SSA & $2000-2012$ & System GMM & $\begin{array}{l}\text { Higher budget deficits leads to } \\
\text { lesser current account deficits. }\end{array}$ \\
\hline $\begin{array}{l}\text { Şen and Kaya } \\
\text { (2016) }\end{array}$ & $\begin{array}{l}\text { Post communist } \\
\text { countries }\end{array}$ & $1994-2012$ & $\begin{array}{l}\text { Bootstrap panel } \\
\text { Granger causal- } \\
\text { ity test }\end{array}$ & $\begin{array}{l}\text { Lack of support for the existence of } \\
\text { the twin deficits hypothesis. }\end{array}$ \\
\hline Kumar (2016) & India & $1970-2013$ & $\begin{array}{l}\text { ARDL bounds } \\
\text { testing }\end{array}$ & $\begin{array}{l}\text { The two deficits are positively relat- } \\
\text { ed, and causality runs from budget } \\
\text { deficits to trade deficits. }\end{array}$ \\
\hline $\begin{array}{l}\text { Magazzino } \\
(2017)\end{array}$ & APEC countries & $1980-2013$ & Panel VAR & $\begin{array}{l}\text { There is a two-way causality be- } \\
\text { tween the two deficits }\end{array}$ \\
\hline $\begin{array}{l}\text { Banday and } \\
\text { Aneja (2018) }\end{array}$ & India & $1990-2015$ & $\begin{array}{l}\text { Cointegration } \\
\text { and error correc- } \\
\text { tion }\end{array}$ & $\begin{array}{l}\text { A two-way causality exist between } \\
\text { the two deficits. }\end{array}$ \\
\hline $\begin{array}{l}\text { Chen } \\
\text { and Liu (2018) }\end{array}$ & China & $\begin{array}{l}\text { 1995-2015 } \\
\text { Quarterly data }\end{array}$ & SVAR & $\begin{array}{l}\text { The twin deficits accompany posi- } \\
\text { tive government consumption and } \\
\text { investment shocks. }\end{array}$ \\
\hline Helmy (2018) & Egypt & $1975-2014$ & VECM & $\begin{array}{l}\text { The results refute the twin deficits } \\
\text { hypothesis. }\end{array}$ \\
\hline $\begin{array}{l}\text { Goyal and } \\
\text { Kumar (2018) }\end{array}$ & India & $\begin{array}{c}\text { 1996-2015 } \\
\text { Quarterly data }\end{array}$ & SVAR & $\begin{array}{l}\text { Current account deficits is affected } \\
\text { by fiscal deficits shock. }\end{array}$ \\
\hline Özata (2014) & Turkey & $\begin{array}{l}\text { 1998-2012 Quar- } \\
\text { terly data }\end{array}$ & SVAR & $\begin{array}{l}\text { Oil imports (rising oil prices) have a } \\
\text { positive effect on current account } \\
\text { deficits. }\end{array}$ \\
\hline
\end{tabular}


Table 1. A Summary of Empirical Literature Review on Twin Deficits (Continued)

\begin{tabular}{|c|c|c|c|c|}
\hline Author(s) & Country(ies) & Period & Method/Model & Findings \\
\hline $\begin{array}{l}\text { Huntington } \\
\text { (2015) }\end{array}$ & Cross country & 1984-2009 & FE and PMG & $\begin{array}{l}\text { Net oil exports contributes to cur- } \\
\text { rent account surpluses. And higher } \\
\text { oil imports have a significant effect } \\
\text { on current account deficits. }\end{array}$ \\
\hline $\begin{array}{l}\text { Bayraktar } \\
\text { et al. (2016) }\end{array}$ & $\begin{array}{l}\text { Developing } \\
\text { countries }\end{array}$ & $1980-2014$ & $\begin{array}{l}\text { Panel cointegra- } \\
\text { tion method }\end{array}$ & $\begin{array}{l}\text { Oil prices and current account are } \\
\text { negatively related, and there is a } \\
\text { one-way causality from oil prices to } \\
\text { current account deficits. }\end{array}$ \\
\hline Besel (2017) & Turkey & $1967-2016$ & $\begin{array}{l}\text { Toda and Yama- } \\
\text { moto causality } \\
\text { test }\end{array}$ & $\begin{array}{l}\text { There is a unidirectional causality } \\
\text { from oil prices to current account } \\
\text { deficits. }\end{array}$ \\
\hline $\begin{array}{l}\text { Musau and Veka } \\
\text { (2018) }\end{array}$ & Multi-country & 1984-2009 & $\begin{array}{l}\text { Toda } \\
\text { and Yamamoto } \\
\text { causality test }\end{array}$ & $\begin{array}{l}\text { There is a positive relation between } \\
\text { net oil export balance and trade } \\
\text { balance. }\end{array}$ \\
\hline
\end{tabular}

Note: FE=Fixed Effects; PMG=Pooled Mean Group; SVAR=Structural Vector Autoregression; VECM=Vector Error Correction Model; GMM=Generalized Method of Moments.

SAARC countries (Ravinthirakumaran, 2016). The empirical evidence from these studies indicate that current account deficits is influenced by budget deficits.

Also, there are studies that have assessed the linkage between oil prices/oil imports and current account balance (see Bayraktar et al., 2016; Besel, 2017; Huntington, 2015; Özata, 2014). The studies found that increases in oil prices and/or higher oil imports are an important determinant of current account deficits.

A summary of the empirical literature review on twin deficits is presented in Table 1.

A survey of the literature suggests that, while empirical studies linking budget deficits to current account deficits abound elsewhere, there is dearth of such studies on Nigeria. In addition, the study conducted on Nigeria by Onafowora and Owoye (2006) employed the conventional cointegration methods (Johansen, 1988; Johansen \& Juselius, 1990), which have been found to be less robust compared to the ARDL and DOLS techniques used in this study when using small samples. Besides, the present study considers oil prices as a potential determinant of current account deficits, and it employs the TodaYamamoto causality procedure which is more robust to examine the causal relationship between the two deficits. Lastly, this study extends the study period to 2017.

\section{Theoretical framework and the model}

In this section, an attempt is made to establish a link between budget deficits and current account deficits. Following the work of Pattichis (2004), this study relies on the Keynesian assertion that rising budget deficits is the major cause of current account deficits.

Assuming there is a simple model for an open economy, in which current account deficits (CAD) is equal to national investment (INV) less national 
savings (SAV) as:

$C A D=I N V-S A V$

Suppose the expression above is re-written as:

$C A D=\left(I N V_{g}-S A V_{g}\right)+\left(I N V_{p}-S A V_{p}\right)$

where:

$\mathrm{INV}_{\mathrm{g}}$ is government investment, $\mathrm{SAV}_{\mathrm{g}}$ is government savings, $\mathrm{INV}_{\mathrm{p}}$ is private sector investment, $\mathrm{SAV}_{\mathrm{p}}$ is private sector savings, and subscripts $\mathrm{g}$ and $\mathrm{p}$ are government sector and private sector, respectively. Thus,

$I N V=I N V_{g}+I N V_{p}$

and

$S A V=S A V_{g}+S A V_{p}$

Moreover, budget deficits (BUD) is the excess of government expenditure over government tax revenue. That is,

$B U D=G O V+I N T+I N V_{a}-T X$

where GOV is government expenditure, INT is interest payments on government debt and TX is government tax revenue. Therefore,

$S A V_{g}=T X-G O V-I N T$

and

$G O V=T X-S A V_{g}-I N T$

Substituting equation 7 into equation 5 leads to:

$B U D=I N V_{g}-S A V_{g}$

Therefore, equation 2 takes the following form:

$C A D=B U D+\left(I N V_{p}-S A V_{p}\right)$

Equation 9 shows that rising government budget deficits leads to an increase in current account defi- cits.

In order to derive a model linking the two deficits, this study borrows the ideas of Soukiazis, Cerqueira and Antunes (2015) and Soukiazis, Antunes and Kostakis (2017). Theoretically, a government can employ an expansionary fiscal policy to enhance overall economic performance including promoting and sustaining high growth rates, increasing investment, reducing unemployment and poverty, and so on. However, such a policy may not lead to the attainment of desirable objectives of boosting growth rates and lowering unemployment (Pelagidis \& Desli, 2004; Soukiazis et al., 2015; 2017). For example, budget deficits which accompany an expansionary fiscal policy raises public debt and interest rates. Consequently, private investment is crowded-out while inflation increases, leading to poor economic growth (Soukiazis et al., 2015; 2017). The decline in investment causes domestic production to reduce, lowering exports and raising imports. All of these result in current account deterioration.

Taking these issues into consideration, an econometric model which captures current account deficits and budget deficits relationship is specified as follows:

$C A D_{t}=\alpha_{0}+\alpha_{1} B U D_{t}+\varepsilon_{t}$

Beside budget deficits (the variable of interest), other important determinants of current account deficits cited in the literature include interest rate (INT) (see Anoruo \& Ramchander, 1998; Baharumshah \& Lau, 2007; Baharumshah et al., 2006; Calderon, Chong \& Loayza, 2000) and oil prices (OILP) (see Bayraktar et al., 2016; Besel, 2017; Özata, 2014). For example, the monetary authority can raise the INT to reduce current account deficits. An increase in interest rate reduces investment. The decline in investment results in less importation of raw materials and investment equipments, leading to a reduction in current account deficits or an improvement in the current account balance. On the other hand, the rise in interest rate can lead to domestic currency appreciation via increased capital inflows. Thus, imports become cheaper and exports less competitive abroad, leading to worsening bal- 
ance of payments position and current account deficits.

In addition, Nigeria is the largest oil and gas producer country in Africa including depending largely on oil export revenues/proceeds. Since a greater percentage of Nigeria's government revenue comes from oil exports and the government is a major player in economic activity, fluctuations in oil prices tend to affect overall economic performance (Abu, 2017). Thus, rising/falling oil prices can influence economic indicators such as GDP, exchange rate, current account balance, among other things. For example, rising oil prices implies an increase in a country's net foreign assets and/or more foreign exchange reserves, meaning higher earnings and a reduction in fiscal pressures. In essence, increases in oil prices can provide additional savings for nations that have huge oil resources (Huntington, 2015). The improvement in fiscal revenue leads to an improvement in the current account balance. On the other hand, falling oil prices leads to decreases in foreign assets/foreign exchange reserves and government revenue, putting fiscal pressures on the economy and worsening the current account position.

Taking the possible impact of oil prices (OILP) and interest rates (INT) into cognizance, the econometric model is re-specified to include OILP and INT as follows:

$C A D_{t}=\alpha_{0}+\alpha_{1} B U D_{t}+\alpha_{2} L O I L P_{t}+\alpha_{3} I N T_{t}+\varepsilon_{t(11)}$

where $\mathrm{L}$ denotes logarithm. The logarithm is taken to reduce the skewness of the series.

\section{Methodology and data}

This study uses annual data covering the 1981-2017 period to investigate the twin deficits hypothesis in Nigeria. The data on current account deficits, budget deficits and interest rates were collected from the Central Bank of Nigeria (CBN) Statistical Bulletin 2017, while data for average oil prices were collected from the Organization of Petroleum Exporting Countries (OPEC) and the International Energy Association (IEA). Current account deficits and budget deficits are expressed as a percentage of the GDP, and the interest rate is measured by the monetary policy rate (MPR).

\subsection{Unit Root Tests}

Economic theory requires that series/variables are stationary (or have no unit root) before estimating the relationship between them to avoid the generation of spurious or meaningless results. To conduct the unit root test, the Augmented Dickey-Fuller (ADF) test (Dickey \& Fuller, 1979) was employed. The ADF equation is specified as follows:

$\Delta y_{t}=\mathrm{a}+\rho y_{t-1}+\theta_{1} \Delta y_{t-1}+\cdots+\theta_{k} \Delta y_{t-k}+\varepsilon_{t}$

where $y_{t}$ is the series, and $\varepsilon_{t}$ the disturbance term.

The hypotheses to be tested are:

H0: $\rho=0$ (unit root)

$\mathrm{H} 1: \rho<0$ (series is stationary)

As a complement to the ADF test, the Phillips-Perron (PP) test (Phillips \& Perron, 1988) was employed. The decision rule states that, if the ADF/PP statistic is less than the critical values at $1 \%, 5 \%$ or $10 \%$, the null hypothesis ( $\mathrm{HO})$ is not rejected. On the other hand, if the $\mathrm{ADF} / \mathrm{PP}$ statistic is greater than the critical values, then the alternative hypothesis (H1) is not rejected.

\subsection{ARDL bounds testing to cointegration}

In an attempt to examine the twin deficits hypothesis for Nigeria, this study employs an ARDL estimation technique (Pesaran \& Shin, 1999; Pesaran, Shin \& Smith, 2001). The ARDL approach can be applied whether the variables are integrated to order one $[\mathrm{I}(1)]$, or a mixture of order zero $[\mathrm{I}(0)]$ and $[\mathrm{I}(1)]$. In addition, the ARDL method has several advantages over other cointegration methods such as the residual-based technique (Engle \& Granger, 1987) and the maximum likelihood test (Johansen, 1988, 1991; Johansen \& Juselius, 1990). The advantages have been discussed extensively in the literature (see Abu, 2017; 2019; Abu \& Staniewski, 2019; Ozturk \& Acaravci, 2010, 2011; Vlahinic \& Jakovac, 2014).

For instance, the ARDL technique is more appropriate compared to the conventional cointegration techniques in ascertaining cointegrating relationships when using small sample sizes. Furthermore, the ARDL technique permits the series to have different optimal lags, but this is seldom the case with the conventional cointegration methods. Moreover, 
the ARDL method employs the single reduced form equation to simultaneously estimate both the shortrun and the long-run parameters, while conventional cointegration methods estimate the parameters using a system of equations. The ARDL model $\left(p, k_{1}, k_{2}, k_{3}\right)$ to be estimated is specified as follows:

$$
\begin{aligned}
& \triangle C A D_{t}=\alpha_{0}+\sum^{p} \alpha_{1 i} \Delta C A D_{t-i}+\sum^{k_{1}} \alpha_{2 i} \Delta B U D_{t-i} \\
& +\sum_{i=0}^{k_{2}} \alpha_{3 i} \Delta L O I L P_{t-i}+\sum_{i=0}^{k_{3}} \alpha_{4 i} \Delta I N T_{t-i} \\
& +\delta_{1} C A D_{t-1}+\delta_{2} B U D_{t-1}+\delta_{3} L O I L P_{t-1}+\delta_{4} I N T_{t-1}+\varepsilon_{t}(13)
\end{aligned}
$$

The procedure of the ARDL model begins with the conduct of the bounds test for the null hypothesis of no cointegration (H0) against the alternative hypothesis (H1) for individual equation stated as follows:

H0: $\delta_{1}=\delta_{2}=\delta_{3}=\delta_{4}=0$, and H1: $\delta_{1} \neq \delta_{2} \neq \delta_{3} \neq \delta_{4} \neq 0$

To achieve this objective, a Wald test (using Fstatistic) for the joint significance of the coefficients is computed, and compared with the upper and lower critical bounds. The decision rule states that if the computed F-statistic is higher than the upper bound [I(1)], the null hypothesis of no cointegration between the variables is rejected. In the event that the computed F-statistic is smaller than the lower bound [I(0)], the null hypothesis of no cointegration between the series is not rejected. Where the F-statistic falls between $\mathrm{I}(0)$ and $\mathrm{I}(1)$, the inference would be inconclusive.

If a long-run relationship is found between current account deficits and budget deficits (along with oil prices and interest rate), then the long-run coefficients will be estimated. The long-run model to be estimated is specified as follows:

$$
C A D_{t}=\Upsilon_{0}+\Upsilon_{1} B U D_{t}+\Upsilon_{2} L O I L P_{t}+\Upsilon_{3} I N T_{t}+\varepsilon_{t}(14)
$$

Also, following a confirmation of a long-run relationship between the variables, the short-run coefficients can be estimated. The short-run model is specified as follows:

$$
\begin{aligned}
& \Delta C A D_{t}=\beta_{0}+\sum_{i=1}^{p} \beta_{1 i} \Delta C A D_{t-i}+\sum_{i=0}^{k_{1}} \beta_{2 i} \Delta B U D_{t-i} \\
& +\sum_{i=0}^{k_{2}} \beta_{3 i} \Delta L O I L P_{t-i}+\sum_{i=0}^{k_{3}} \beta_{4 i} \Delta I N T_{t-i} \\
& +\theta_{1} E C T_{t-1}+\varepsilon_{t}
\end{aligned}
$$

The error correction term $\left(E C T_{t-1}\right)$ in Equation 14 shows the speed of adjustment required to restore the long-run equilibrium following any deviation or shock. The coefficient of the lagged one period error correction term $\left(\theta_{1}\right)$ represents the speed of adjustment.

In estimating the ARDL model, the optimal lags for the variables are chosen using the Akaike Information Criteria (AIC). The AIC is preferred because it performs better than other lag selection criteria when determining the optimal lag length for a small sample size (Liew, 2004). In addition, Lutkepohl (1991) cited in Tang and Lean (2007a) submitted that the AIC is superior to other information criterion including the Schwarz Bayesian criterion (SBC) in finite samples.

\subsection{Diagnostic Tests}

To ascertain the reliability or validity of the results generated using the ARDL technique, diagnostic tests will be conducted. These tests reveal whether or not the estimated model has serial-correlation and heteroscedasticity problems including checking if the model has problems relating to normality and functional form.

The Jarque-Bera test is used to check if the residuals are normally distributed, while the Breusch-Godfrey Serial Correlation Lagrange Multiplier test is used to ascertain whether the residuals are serially correlated. Also, the Breusch-Pagan-Godfrey Heteroscedasticity test is employed to check if the disturbance term in the model is homoscedastic, and the Ramsey Reset test to ascertain if there is omitted variable bias in the model or if the model is correctly specified.

\subsection{Stability Tests}

The stability test for the model (and estimated parameters) will be conducted using the cumulative sum of recursive residuals (CUSUM) and cumulative sum of squares of recursive residuals (CUSUMQ) tests. The parameters will be said to be unstable if the plots of the CUSUMQ breaks in the lower or upper bounds (Greene, 2003; Tang \& Lean, 2007b).

\subsection{DOLS estimation}

In an attempt to ascertain the consistency and robustness of the estimates generated using the ARDL approach, the DOLS method (Saikkonen, 1992; Stock 
\& Watson, 1993) was employed to examine the longrun relationship between the two deficits. As stated earlier, both ARDL and DOLS estimators deal with endogeneity bias and provide more efficient results in small sample sizes (Alhassan \& Fiador, 2014; Montalvo, 1995; Narayan \& Narayan, 2004; Singh, 2015; Stock \& Watson, 1993). The DOLS model is specified as:

$Y_{t}=\alpha+\beta X_{t}+\sum_{j=-q}^{q} \theta_{j} \Delta X_{t-j}+\varepsilon_{t}$

where $Y$ is the dependent variable (current account deficits), $X$ the explanatory variable(s) (budget deficits, interest rate and oil prices), and $q$ is the numbers of lags or leads which is/are chosen using the AIC. The procedure entails regressing one of the $\mathrm{I}(1)$ variables on other $\mathrm{I}(1)$ variables, the $\mathrm{I}(0)$ variables, and lags and leads of the first difference of the I(1) variables. This removes simultaneity bias inherent among the regressors. Using the DOLS ensures that any endogeneity of the regressors will have no impact on the robustness of the estimates generated (Narayan \& Narayan, 2004). Moreover, Stock and Watson (1993) revealed that the DOLS estimator is better when dealing with finite samples.

\subsection{Causality Test}

A confirmation of cointegration between budget deficits and current account deficits (along with oil prices and interest rate) provides the justification for conducting causality test to check the direction of causality between the twin deficits. Granger (1986) suggested that if variables are cointegrated or have a long-run relationship, then causality will exist at least in one direction. To this end, the Toda and Yamamoto (1995) approach will be employed to perform the causality test. As stated earlier, the standard Granger causality test is more sensitive to problems with residuals in small samples compared to the Toda-Yamamoto causality test. The Toda- Yamamoto procedure employs a modified Wald test which can be used if the series are $\mathrm{I}(0)$ and $\mathrm{I}(1)$. This augmented Granger causality test uses the seemingly unrelated regression method by estimating a two-equation system (Raza \& Jawaid, 2014). By using the seemingly unrelated regression models for estimation the Wald test enhances its efficiency. The model is specified as follows:

$$
\begin{aligned}
& C A D_{t}=\alpha_{1}+\sum_{i=1}^{k+d} \pi_{1 i} C A D_{t-i}+\sum_{t-i}^{k+d} \pi_{2 i} B U D_{t-i} \\
& +\varepsilon_{2 t} \\
& +\sum_{i=1}^{k+d} \pi_{3 i} L O I L P_{t-i}+\sum_{t-i}^{k+d} \pi_{4 i} I N T_{t-i} \\
& B U D_{t}=\alpha_{1}+\sum_{i=1}^{k+d} \varphi_{1 i} C A D_{t-i}+\sum_{t-i}^{k+d} \varphi_{2 i} B U D_{t-i} \\
& +\sum_{i=1}^{k+d} \varphi_{3 i} L_{\text {LOILP }}+\sum_{t-i}^{k+d} \varphi_{4 i} I N T_{t-i}
\end{aligned}
$$

where $k=$ optimal lag order;

$d=$ maximum order of integration of the series; and $\varepsilon_{2 t}$ and $\varepsilon_{3 t}=$ disturbance terms.

Next, the Wald test is applied to the matrices of the first $\mathrm{k}$ coefficient. The null hypotheses to be tested are:

(i) $B U D_{t}$ Granger causes $C A D_{i}$ if $\pi_{2 i} \neq 0$

(ii) $C A D_{t}$ Granger causes $B U D_{i}$ if $\varphi_{1 i} \neq 0$

\section{Results and Discussion}

Prior to investigating the current account and budget deficits relationship, we computed the descriptive statistics and conducted correlation analysis on the variables.

\subsection{Descriptive Statistics}

The descriptive statistics in Table 2 indicate that the mean current account balance is 4.03 , implying that average current account balance was surplus during the 1981-2017 period.

On the other hand, average overall budget balance is -1.79 , indicating that overall budget balance was in deficits during the same period. Additionally, the mean interest rate is 12.94 , while the mean logarithm of oil prices is 3.47 .

\subsection{Correlation Analysis}

The correlation analysis results (Table 3 ) show that current account balance and budget balance (the variables of interest) have a strong and positive correlation (i.e. 0.7841), and the relationship is significant at $1 \%$ level. The results also indicate that current account balance and oil prices have a positive and weak correlation (i.e. 0.4141), and the relationship is significant at $5 \%$ level. However, the correlation between current account balance and interest rate is negative and weak (i.e. -0.2081), and the relationship is insignificant. 
Table 2. Descriptive Statistics

\begin{tabular}{|c|c|c|c|c|c|}
\hline Variable & Mean & Stand. Dev. & Min. & Max. & Obs. \\
\hline CAD & 4.0305 & 8.9897 & -11.5000 & 32.8000 & 37 \\
\hline BUD & -1.7981 & 4.9139 & -9.7000 & 10.0000 & 37 \\
\hline LOILP & 3.4753 & 0.6669 & 2.5079 & 4.6954 & 37 \\
\hline INT & 12.9375 & 4.0150 & 6.0000 & 26.0000 & 37 \\
\hline
\end{tabular}

Table 3. Correlation Matrix

\begin{tabular}{lccc}
\hline & CAD & BUD & LOILP \\
\hline CAD & 1.0000 & & \\
BUD & $0.7841^{* * *}$ & & \\
& $(7.4759)$ & 1.0000 & \\
LOILP & $0.4142^{* *}$ & $0.4830^{* * *}$ & 1.0000 \\
& $(2.6919)$ & $(3.2634)$ & \\
INT & -0.2081 & -0.1750 & $(-3.1584)$ \\
\hline
\end{tabular}

Note: ${ }^{* *}$ and ${ }^{* \star}$ denotes statistical significance at $1 \%$ and $5 \%$, respectively. Numbers in parenthesis are t-statistics.

Moreover, there is a positive and weak correlation between budget deficits and oil prices (i.e. 0.4830), but the relationship is significant at $1 \%$ level. Furthermore, budget deficits and interest rate have a negative and weak correlation (i.e. $-0.1750)$, and the relationship is not significant. In addition, interest rate and oil prices have a nega- tive and weak correlation (i.e. -0.4710), and the relationship is significant at $1 \%$ level. Also, the the correlation coefficients of the pairs - CAD and BUD, CAD and INT, and LOILP and INT have the expected signs. On the other hand, the sign of the correlation coefficients of the remaining pairs did not meet our expectations. 


\subsection{Results of Unit Root Tests}

The results of the unit root tests reported in Table 4 demonstrate that the series are a mixture of $\mathrm{I}(0)$ and $\mathrm{I}(1)$, because some variables are stationary at level while the remainder is stationary after taking its first difference.

Specifically, CAD, BUD and INT are stationary at level (i.e. I(0)), while LOILP is stationary after its first difference was taken (i.e. I(1)).

\subsection{Result of Bounds Testing to Cointegration}

Having found the series to be a mixture of $\mathrm{I}(0)$ and $\mathrm{I}(1)$, the ARDL bounds testing technique was employed to check if there is cointegration between the variables. The result of the bounds testing to cointegration reported in Table 5 reveals that the computed F-statistic (7.9028) is larger than the upper critical bound at $1 \%$ level. Thus, the null hypothesis of no cointegration between the series is rejected. This indicates that there is cointegration or a long-run relationship between the variables.

\subsection{Results of Estimation of the ARDL Model}

Given the confirmation of a long-run relationship between the variables, the ARDL model was estimated taking into consideration the optimal lag-length $(3,1,3,3)$, as suggested by the Akaike Information Criterion.

The results of the long-run and short-run selected models are reported in Table 6 . The results show that budget deficits has a positive and significant effect on current account deficits both in the long-run and the short-run at $1 \%$ level. A one percentage increase in budget deficits (as a \% of GDP) leads to a 1.91 percentage increase in current account deficits (as a \% of GDP) in the long-run. Similarly, a one percentage increase in budget deficits results in a 0.87 percentage increase in current account deficits in the shortrun. This finding is consistent with the ones reported in previous studies on developing countries (see Baharumshah \& Lau, 2007; Onafowora \& Owoye, 2006; Saleh, Nair \& Agalewatte, 2005; Vamvoukas, 1999). For example, Onafowora and Owoye (2006) confirmed the existence of the twin deficits phenomenon for Nigeria in the short-run and the long-run. Also, Saleh et al. (2005) discovered that budget deficits has a positive and significant effect on current account deficits in Sri Lanka in the long-run. On their part, Baharumshah and Lau (2007) found a significant and positive relationship between the two deficits for Thailand in the short-run. Thus, a reduction in budget deficits (or an improvement in the overall budget balance) leads to a reduction in current account deficits (or an improvement in the current account position), and vice versa.

The results also illustrate that the coefficient of oil prices is negative and significant in the long-run at $10 \%$ level. A one percentage increase in log of oil prices leads to a reduction in the current account deficits by 0.05 percentage in the long-run. This finding lends support to the outcome of previous studies (see Bayraktar et al., 2016; Huntington, 2015; Musau \& Veka, 2018). Thus, a rise in oil prices leads to an increase in Nigeria's net foreign assets or savings, causing an improvement in overall budget balance and lowering current account deficits.

Furthermore, interest rate has a negative and significant effect on the current account balance in the short-run at $10 \%$ level. A one percentage increase in interest rate (measured in \%) causes current account deficits to reduce by a 0.41 percentage in the shortrun. This finding lends support to the findings of previous studies (Baharumshah \& Lau, 2007; Calderón et al., 2000). The negative sign of the interest rate coefficient suggests that an increase in interest rate reduces not only investment but consumption as well. This in turn reduces importation of raw materials and investment equipments, leading to a reduction in current account deficits.

Moreover, current account deficits lagged by two periods has a negative and significant effect of current account at $1 \%$ level. A one percentage increase in current account deficits lagged by two periods leads to a decrease in current account deficits by 0.46 percentage. This finding is consistent with prior studies which discovered that past values of current account deficits have a significant negative effect on its current values (see Ahmed \& Ansari; Aloryito et al., 2016; Aqeel \& Nishat, 2000; Baharumshah \& Lau, 2007). This negative relationship implies a partial adjustment to equilibrium following any shock or deviation.

The coefficient of the error correction term lagged by one period was found to be statistically significantand correctly signed at $1 \%$ level. This implies that 
Table 4. Results of Unit Root Tests

\begin{tabular}{|c|c|c|c|c|}
\hline \multicolumn{3}{|c|}{ ADF } & \multicolumn{2}{|c|}{ PP } \\
\hline Variable & Level & 1st Diff. & Level & 1st Diff. \\
\hline CAD & $-2.7971^{\star}$ & - & $-2.7365^{*}$ & - \\
\hline BUD & $-2.9805^{\star *}$ & - & $-2.9058^{*}$ & - \\
\hline LOILP & -1.0933 & $-5.7880^{* * *}$ & -1.0768 & $-5.7880^{\star * *}$ \\
\hline INT & $-3.1176^{\star *}$ & - & $-3.00569^{* *}$ & - \\
\hline
\end{tabular}

Note: ${ }^{* *},{ }^{* *}$ and ${ }^{\star}$ denotes statistical significance at $1 \%, 5 \%$ and $10 \%$, respectively.

Table 5. Results of Bounds Test to Cointegration

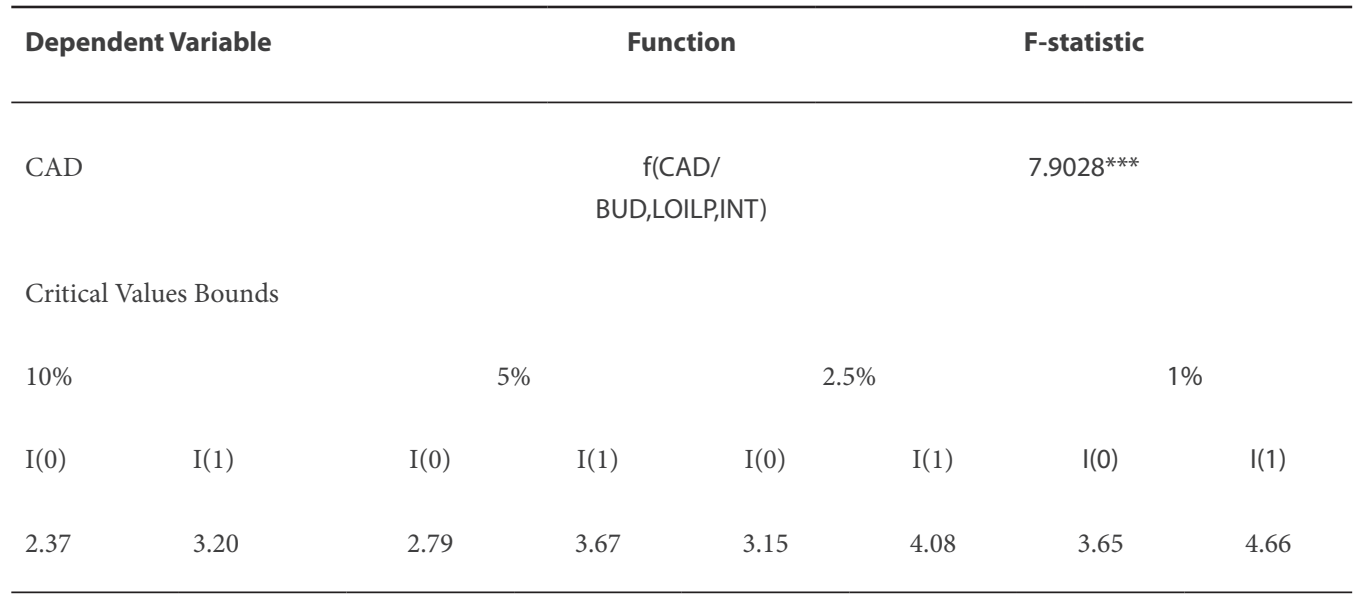

Note: ${ }^{* *}$ denotes statistical significance at $1 \%$. L denotes logarithm.

Table 6. Results of the ARDL Model

\section{Panel A: Long-run Coefficients - Dependent variable is CAD}

\begin{tabular}{|c|c|c|c|}
\hline Regressor & Coefficient & Std Error & t-ratio \\
\hline C & 28.7679 & 12.1475 & $2.3682^{* *}$ \\
\hline BUD & 1.9094 & 0.4344 & $4.3956^{\star * *}$ \\
\hline
\end{tabular}


Table 2. Results of the ARDL Model (Continued)

\section{Panel A: Long-run Coefficients - Dependent variable is CAD}

\begin{tabular}{|c|c|c|c|}
\hline Regressor & Coefficient & Std Error & t-ratio \\
\hline LOILP & -5.0782 & 2.5151 & $-2.0190^{*}$ \\
\hline INT & -0.2898 & 0.3732 & -0.7764 \\
\hline \multicolumn{4}{|c|}{ Panel B: Short-run Coefficients - Dependent variable is $\triangle C A D$} \\
\hline Regressor & Coefficient & Std Error & t-ratio \\
\hline$\Delta \mathrm{CAD}_{-1}$ & 0.0196 & 0.0977 & 0.2011 \\
\hline$\Delta \mathrm{CAD}_{-2}$ & -0.4583 & 0.1028 & $-4.4583^{* * *}$ \\
\hline$\triangle \mathrm{BUD}$ & 0.8660 & 0.2189 & $3.9577^{* * *}$ \\
\hline$\Delta$ LOILP & 3.9012 & 2.6736 & 1.4591 \\
\hline$\Delta$ LOILP $_{-1}$ & 1.0621 & 2.8739 & 0.3695 \\
\hline$\Delta$ LOILP $_{-2}$ & 7.6000 & 2.9603 & $2.5672^{\star * *}$ \\
\hline$\Delta \mathrm{INT}$ & -0.4146 & 0.2044 & $-2.0275^{\star}$ \\
\hline$\Delta \mathrm{INT}_{-1}$ & 0.1631 & 0.2040 & 0.7992 \\
\hline$\Delta \mathrm{INT}_{-2}$ & -0.7947 & 0.2038 & $-3.8986^{\star \star \star}$ \\
\hline $\mathrm{ECT}_{-1}$ & -0.7871 & 0.1143 & $-6.8860^{* * *}$ \\
\hline $\mathrm{R}^{2}$ & 0.8659 & & \\
\hline
\end{tabular}

Note: ${ }^{\star * \star}, * \star$, and ${ }^{\star}$ denotes statistical significance at $1 \%, 5 \%$ and $10 \%$, respectively. L denotes logarithm.

78.7\% of any deviations from the equilibrium will be corrected within one year.

\subsection{Results of Diagnostic Tests}

The results of diagnostic tests presented in Table 7 show that the ARDL model does not have problems relating serial-correlation, functional form, normality and heteroscadasticity. Specifically, the Jarque-Bera test indicates that the residuals are normally distributed at $1 \%$ level, and the Lagrange Multiplier test illustrates the absence of serial-correlation among the residuals at $1 \%$ level. Moreover, the Breusch-Pagan-Godfrey heteroscedasticity test reveals that the error/disturbance term in the model is homoscedastic at 1\% level, and the Ramsey Reset test result dem- 
onstrates that there is no omitted variable bias or specification error at $5 \%$ level.

\subsection{Results of Stability Tests}

The results of the cumulative sum of recursive residuals (CUSUM) and cumulative sum of squares of recursive residuals (CUSUMQ) tests indicate that the plots of the CUSUM (Figure 2) and CUSUMQ (Figure 3) are within the boundaries. This implies that the estimated parameters and model are stable over the longrun.

\subsection{Results of the DOLS Model}

The DOLS model was estimated using lead and lag length of 1 (based on the AIC) with White heteroscedasticity-consistent standard error and covariance. The results of estimation (Table 8) show that budget deficits has a long-run positive and significant effect on current account deficits at $1 \%$ level. A one percentage increase in budget deficits leads to a 2.23 percentage increase in current account deficits. In addition, oil prices has a negative and significant effect on current account deficits at $1 \%$ level. A one percentage increase in oil prices leads to approximately a 0.05 percentage decrease in current account deficits. Similarly, interest rate has a negative and significant effect on current account deficits at 5\% level. A one percentage increase in interest rate reduces current account deficits by a 0.63 percentage.

Overall, the results of estimations of the ARDL and
DOLS models show that budget deficits has a longrun positive and significant effect on current account deficits. Also, the coefficient of budget deficits (the variable of interest) is 1.91 and 2.23 in the ARDL and DOLS estimates, respectively. In the same vein, the coefficient of oil prices is -5.08 and -4.84 in the ARDL and DOLS estimates, respectively. Since these longrun coefficients are closer (in values), it implies that the results are consistent and robust.

\subsection{Results of Causality Tests}

Given that the objective here is to ascertain the direction of causality between the two deficits, our focus is on the causal relationship between current account deficits and budget deficits. The results of the TodaYamamoto causality test (Table 9) demonstrate that current account deficits Granger causes budget deficits at $1 \%$ level, and not vice versa. This implies that there is a unidirectional or one-way causality from current account deficits to budget deficits. This outcome is consistent with the ones reported that causality runs from current account (trade) deficits to budget deficits for developing economies including Nigeria (see Anoruo \& Ramchander, 1998; Baharumshah \& Lau, 2009; Onafowora \& Owoye, 2006).

However, this finding is inconsistent with those that found a unidirectional causality from budget deficits to current account deficits in developing countries. For example, Saleh et al. (2005) confirmed the existence of a one-way causality from budget deficits

Table 7. ARDL-ECM Model Diagnostic Tests

\begin{tabular}{lc}
\hline Test Statistic & Results \\
\hline Serial Correlation: $\chi^{2}$ & $2.9904[0.2369]$ \\
Functional Form: Reset F-stat. & $2.4415[0.0996]$ \\
Normality: Jarque-Bera & $3.1857[0.2033]$ \\
& \\
\hline Heteroscedasticity: $\chi^{2}$ & $11.0059[0.6103]$ \\
\hline
\end{tabular}

Note: Probability values are in parenthesis 


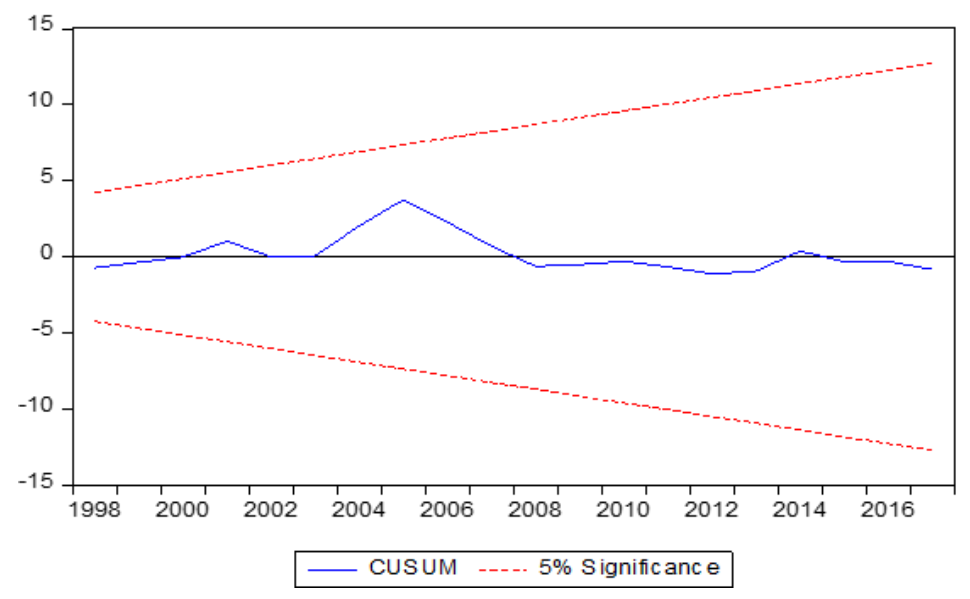

Figure 2. Plots of cumulative sum of recursive residuals.



Figure 3. Plots of cumulative sum of squares of recursive residuals. 
Table 8. Results of the DOLS Model

\begin{tabular}{|c|c|c|c|}
\hline \multicolumn{4}{|c|}{ Dependent Variable - CAD } \\
\hline Regressor & Coefficient & Std Error & t-ratio \\
\hline C & 33.0130 & 8.3619 & $3.9479 * * *$ \\
\hline BUD & 2.2349 & 0.2976 & $7.5087^{* * *}$ \\
\hline LOILP & -4.8369 & 1.5992 & $-3.0245^{\star * *}$ \\
\hline INT & -0.6284 & 0.2790 & $-2.2525^{\star *}$ \\
\hline $\mathrm{R}^{2}$ & 0.8480 & & \\
\hline
\end{tabular}

Note: ${ }^{* \star}$ and ${ }^{* \star}$ denotes statistical significance at $1 \%$ and $5 \%$, respectively. L denotes logarithm.

Table 9. Results of Toda-Yamamoto Causality Test

\begin{tabular}{|c|c|c|c|c|}
\hline Null Hypothesis & Chi-Sq. & D.f & Prob. & Decision \\
\hline BUD Granger causes CAD & 5.8189 & 5 & 0.3242 & Null Hypothesis isRejected \\
\hline CAD Granger causes BUD & 25.169 & 5 & 0.0001 & Null Hypothesis is not Rejected \\
\hline LOILP Granger causes CAD & 5.7093 & 5 & 0.3355 & Null Hypothesis is Rejected \\
\hline CAD Granger causes LOILP & 16.568 & 5 & 0.0054 & Null Hypothesis is not Rejected \\
\hline INT Granger causes CAD & 9.0999 & 5 & 0.1051 & Null Hypothesis is Rejected \\
\hline CAD Granger causes INT & 14.227 & 5 & 0.0142 & Null Hypothesis is not Rejected \\
\hline INT Granger causes BUD & 14.609 & 5 & 0.0122 & Null Hypothesis is not Rejected \\
\hline BUD Granger causes INT & 9.9262 & 5 & 0.0774 & Null Hypothesis is not Rejected \\
\hline BUD Granger causes LOILP & 11.619 & 5 & 0.0404 & Null Hypothesis is not Rejected \\
\hline LOILP Granger causes BUD & 15.873 & 5 & 0.0072 & Null Hypothesis is not Rejected \\
\hline INT Granger causes LOILP & 8.9970 & 5 & 0.1092 & Null Hypothesis is Rejected \\
\hline LOILP Granger causes INT & 11.756 & 5 & 0.0383 & Null Hypothesis is not Rejected \\
\hline
\end{tabular}


to current account deficits in Sri Lanka. Similarly, Pattichis (2004) discovered that causality runs from budget deficits to current account (trade) deficits for Lebanon, and Vamvoukas (1999) found a one-way causality from budget deficits to trade deficits in Greece.

\section{Conclusions}

This paper examines the twin deficits hypothesis for Nigeria during the 1981-2017 period using the ARDL and DOLS estimators. The result of the bounds testing to cointegration reveals that there is a longrun relationship between budget deficits and current account deficits (along with oil prices and interest rate). The results of estimations confirm the validity of the twin deficits hypothesis for Nigeria because increases in budget deficits lead to increases in current account deficits in the long-run. This finding validates the Keynesian claim that an increase in budget deficits leads to an increase in current account deficits. However, this outcome is inconsistent with the Ricardian Equivalence Hypothesis that the two deficits are not related. The results of the TodaYamamoto causality test indicate that current account deficits Granger causes budget deficits, and not vice versa.

Based on these findings, this study recommends policies to check the two deficits from worsening in Nigeria. To this end, government should take steps in reducing budget deficits to check the current account from deteriorating. Also, government should make efforts to boost oil production and exports so as to increase its foreign assets. An increase in net foreign assets/savings will reduce the current account deficits. In addition, authorities in Nigeria should employ measures to manage the interest rates appropriately in order to improve the current account position/balance. Lastly, government should take steps to discourage importation of commodities or items which can be produced locally and have become a conduit pipe for the depletion of the nation's scarce resources. These measures will go a long way in reducing both budget and current account deficits.

\section{References}

Abu, N. (2017). Does Okun's law exist in Nigeria? Evidence from ARDL bounds testing approach. Con- temporary Economics, 11(2), 131-144.

Abu, N. (2019). Inflation and unemployment trade-off: A re-examination of the Phillips curve and its stability in Nigeria. Contemporary Economics, 13(1), 21-34.

Abu, N., \& Staniewski, M. W. (2019). Determinants of corruption in Nigeria: Evidence from various estimation techniques. Economic Research-Ekonomska Istraživanja, 32(1), 3052-3076.

Ahmad, A. H., Aworinde, O. B., \& Martin, C. (2015). Threshold cointegration and the short-run dynamics of twin deficit hypothesis in African countries. Journal of Economic Asymmetries, 12, 80-91.

Ahmed, S. M., \& Ansari, M. I. (1994). A tale of two deficits: An empirical investigation for Canada. International Trade Journal, 8(4), 483-503.

Alhassan, A. L., \& Fiador, V. (2014). Insurance-growth nexus in Ghana: An autoregressive distributed lag bounds cointegration approach. Review of Development Finance, 4(2), 83-96.

Aloryito, G. K., Senadza, B., \& Nketiah-Amponsah, E. (2016). Testing the twin deficits hypothesis: Effect of fiscal balance on current account balanceA panel analysis of Sub-Saharan Africa. Modern Economy, 7, 945-954.

Alse, J., \& Bahmani-Oskooee, M. (1992). Are the twin deficits really related? A comment. Contemporary Policy Issues, 10, 108-111.

Anoruo, E., \& Ramchander, S. (1998). Current account and fiscal deficits: Evidence from five developing economies of Asia. Journal of Asian Economics, 9(3), 487-501.

Aqeel, A., \& Nishat, M. (2000). The twin deficits phenomenon: Evidence from Pakistan. Pakistan Development Review, 39(4), 535-550.

Aristovnik, A. (2008). Short-term determinants of current account deficits: Evidence from Eastern Europe and the former Soviet Union. Eastern European Economics, 46(1), 24-42.

Aristovnik, A., \& Djurić, S. (2010). Twin deficits and the Feldstein-Horioka puzzle: A comparison of the EU member states and candidate countries. MPRA Paper, 24149.

Arora, H. K., \& Dua, P. (1993). Budget deficits, domestic investment and trade deficits.Contemporary Policy Issues, 11, 29-44.

Aslan, M., Buyrukoglu, S., Oz, E., \& Nazlioglu, S. (2014). Does fiscal policy matter for trade balance in the OECD countries? Panel vector error correction estimation. International Journal of Trade and Global Markets, 7(4), 271-284.

Bachman, D. D. (1992). Why is the U.S current account 
deficit so large? Evidence from vector autoregressions.Southern Economic Journal, 59(2), 232-240.

Baharumshah, A. Z., Lau, E., \& Khalid, A. M. (2006). Testing twin deficits hypothesis using VARs and variance decomposition. Journal of the Asia Pacific Economy, 11(3), 331-354.

Baharumshah, A. Z., \& Lau, E. (2007). Dynamics of fiscal and current account deficits in Thailand: An empirical investigation. Journal of Economic Studies, 34(6), 454-475.

Baharumshah, A. Z., \& Lau, E. (2009). Structural breaks and the twin deficits hypothesis: Evidence from East Asian countries. Economics Bulletin, 29(4), 1-7.

Banday, U. J., \& Aneja, R. (2018). Does fiscal deficit affect current account deficit in India? An econometric analysis. Review of Market Integration, 9(3) $1-20$.

Basu, S., \& Datta, D. (2005). Does fiscal deficit influence trade deficit?: An econometric enquiry. Economic and Political Weekly, 40(30), 3311-3318.

Bayraktar, Y., Egri, T., \& Yildiz, F. (2016). A causal relationship between oil prices, current account deficit, and economic growth: An empirical analysis from fragile five countries. Ecoforum Journal, 5(3), 29-44.

Besel, F. (2017). Oil prices affect current account deficit: Empirical evidence From Turkey. Journal of Applied Research in Finance and Economics, 3(2), 13-21.

Bluedorn, J., \& Leigh, D. (2011). Revisiting the twin deficits hypothesis: The effect of fiscal consolidation on the current account.IMF Economic Review, 59, 582-602.

Bollano, J., \& Ibrahimaj, D. (2015). Current account determinants in Central and Eastern European Countries. Graduate Institute of International and Development Studies Working Paper, 22/2015.

Calderón, C., Chong, A., \& Loayza, N. (2000). Determinants of current account deficits in developing countries. Policy Research Working Paper, 2398.

Cavdar, S. C., \& Aydin, A. D. (2015). Understanding the factors behind current account deficit problem: A panel logit approach on 16 OECD member countries. Procedia Economics and Finance, 30, 187-194.

Chen, Y., \& Liu, D. (2018). Government spending shocks and the real exchange rate in China: Evidence from a sign-restricted VAR model. Economic Modelling, 68, 543-554.

Chinn, M. D., \& Prasad, E. S. (2003). Medium-term determinants of current accounts in industrial and developing countries: An empirical exploration.Journal of International Economics, 59(1), 47-76.

Daly, V., \& Siddiki, J. U. (2009). The twin deficits in OECD countries: Cointegration analysis with regime shifts. Applied Economics Letters, 16(11), 1155-1164.

Dickey, D. A., \& Fuller, W. A. (1979). Distribution of the estimators for autoregressive time series with a unit root. Journal of the American statistical association, 74(366a), 427-431.

Enders, W., \& Lee, B-S. (1990). Current account and budget deficits: Twins or distant cousins? Review of Economics and Statistics, 72(3), 373-381.

Engle, R. F., \& Granger, C. J. (1987). Cointegration and error-correction - Representation, estimation and testing. Econometrica, 55(2), 251-278.

Forte, F., \& Magazzino, C. (2013). Twin deficits in the European countries. International Advances in Economic Research, 19(3), 289-310.

Goyal, A., \& Kumar, A. (2018). The effect of oil shocks and cyclicality in hiding Indian twin deficits. Journal of Economic Studies, 45(1), 27-45.

Granger, C. W. J. (1986). Development in the study of cointegrated economic variables. Oxford Bulletin of Economics and Statistics, 48(3), 213-228.

Greene, W. (2003). Econometric Analysis. $5^{\text {th }}$ ed. New Jersey: Prentice Hall.

Grier, K., \& Ye, H. (2009). Twin sons of different mothers: The long and short of the twin deficits debate. Economic Inquiry, 47(4), 625-638.

Hatemi-J, A.,\& Shukur, G. (2002). Multivariatebased causality tests of twin deficits in the US. Journal of Applied Statistics, 29(6), 817-824.

Helmy, H. E. (2018). The twin deficit hypothesis in Egypt. Journal of Policy Modeling, 4(2), 328-349.

Huntington, H. G. (2015). Crude oil trade and current account deficits. Energy Economics, 50, 70-79.

Idil, U. Z. (2010). Determinants of current account: The relationship between internal and external balances in Turkey. Applied Econometrics and International Development, 10(2), 115-126.

Islam, M. F. (1998). Brazil's twin deficits: An empirical examination. Atlantic Economic Journal, 26(2), 121-128.

Johansen, S. (1988). Statistical analysis of cointegration vectors. Journal of Economic Dynamics and Control, 12(2-3), 231-254.

Johansen, S. (1991). Estimation and hypothesis testing of cointegration vectors in Gaussian vector autoregressive models. Econometrica, 59(6), 1551-1580.

Johansen, S., \& Juselius, K. (1990). Maximum likeli- 
hood estimation and inference on cointegration - With applications to the demand for money. Oxford Bulletin of Economics and Statistics, 52(2), 169-210.

Kalou, S., \& Paleologou, S. (2012). The twin deficits hypothesis: Revisiting an EMU country. Journal of Policy Modeling, 34, 230-241.

Katircioglu, S. T., Fethi, S., \& Fethi, M. D. (2009). Twin deficits phenomenon in small islands: An empirical investigation by panel data analysis. Applied Economics Letters, 16(15), 1569-1573.

Khalid, A. M., \& Guan, T. W. (1999). Causality tests of budget and current account deficits: Crosscountry comparisons. Empirical Economics, 24, $389-402$

Kiran, B. (2011). On the twin deficits hypothesis: Evidence from Turkey. Applied Econometrics and International Development, 11(1), 59-66.

Kouassi, E., Mougoué, M., \& Kymn, K. O. (2004). Causality tests of the relationship between the twin deficits. Empirical Economics, 29,503-525.

Kumar, P. S. (2016). Twin deficit hypothesis: Some recent evidence from India. Global Business and Economics Review, 18(3-4), 487-495.

Lau, E., \& Baharumshah, A. Z. (2004). On the twin deficits hypothesis: Is Malysia different? Pertanika Journal of Social Sciences and Humanities, 12(2), 87-100.

Lau, E., \& Baharumshah, A. Z. (2006). Twin deficits hypothesis in SEACEN countries: A panel data analysis of relationship between public budget and current account deficits. Applied Econometrics and International Development, 6(2), 213-226.

Lau, E., Mansor, S. A., \& Puah, C-H. (2010). Revival of the twin deficits in Asian crisis affected countries. Economic Issues, 15(1), 29-53.

Leachman, L. L., \& Francis, B. (2002). Twin deficits: Apparition or reality?. Applied Economics, 34(9), 1121-1132.

Liew, V. K-S. (2004). Which lag length selection criteria should we employ? Economics Bulletin, 3(33), 1-9.

Lutkepohl, H. (1991). Introduction to Multiple Time Series Analysis. Springer-Verlag, Germany.

Magazzino, C. (2017). Twin deficits or Ricardian Equivalence? Empirical evidence in the APEC countries. Asian Economic and Financial Review, 7(10), 959-971.

Marinheiro, C. F. (2008). Ricardian equivalence, twin deficits, and the Feldstein-Horioka puzzle in Egypt. Journal of Policy Modeling, 30, 1041-1056.

Montalvo, J. G. (1995). Comparing cointegrating re- gression estimators: Some additional Monte Carlo results. Economics Letters, 48, 229-234.

Mukhtar, T., Zakaria, M., \& Ahmed, M. (2007). An empirical investigation for the twin deficits hypothesis in Pakistan. Journal of Economic Cooperation and Development, 28(4), 63-80.

Mumtaz, K., \& Munir, K. (2016). Dynamics of twin deficits in South Asian countries. MPRA Paper, 74592 .

Musau, A., \& Veka, S. (2018). Crude oil trade and current account deficits: Replication and extension. Empirical Economics, 1-23.

Nadenichek, J. (2016). A cross-country test of Ricardian Equivalence and the twin deficits hypothesis. International Journal of Applied Economics, 13(1), $32-42$.

Narayan, S., \& Narayan, P. K. (2004). Determinants of demand for Fijis exports: An empirical investigation. Developing Economies, 42(1), 95-112.

Onafowora, O. A., \& Owoye, O. (2006). An empirical investigation of budget and trade deficits: The case of Nigeria. Journal of Developing Areas, 39(2), 153 174.

Özata, E. (2014). Sustainability of current account deficit with high oil prices: Evidence from Turkey. International Journal of Economic Sciences, 3(2). 71-88.

Ozturk, I., \& Acaravci, A. (2010). The causal relationship between energy consumption and GDP in Albania, Bulgaria, Hungary and Romania: Evidence from ARDL bounds testing approach. Applied Energy, 87(6), 1938-1943.

Ozturk, I., \& Acaravci, A. (2011). Electricity consumption and real GDP causality nexus: Evidence from ARDL bounds testing approach for 11 MENA countries. Applied Energy, 88(8), 2885-2892.

Paparas, D., Richter, C., \& Mu, H. (2016). An econometric analysis of the twin deficits hypothesis in Greece during the period 1960-2014. Applied Economics Quarterly, 62(4), 341-360.

Pattichis, C. (2004). Budget and trade deficits in Lebanon. Applied Economics Letters, 11(2), 105-108.

Pelagidis, T., \& Desli, E. (2004). Deficits, growth and the current slowdown: What role for fiscal policy?. Journal of Post Keynesian Economics, 26(3), 461469.

Pesaran, H. M., \& Shin, Y. (1999). Autoregressive distributed lag modelling approach to cointegration analysis. In: Storm, S. Editor. econometrics and economic theory in the $20^{\text {th }}$ century; The Ragnar Frisch centennial symposium. Cambridge University Press, (chapter 11) 
Pesaran, M. H., Shin, Y., \& Smith R. J. (2001). Bounds testing approaches to the analysis of level relationships. Journal of Applied Econometrics, 16, 289326.

Phillips, P. C., \& Perron, P. (1988). Testing for a unit root in time series regression. Biometrika, 75(2), 335-346.

Piersanti, G. (2000). Current account dynamics and expected future budget deficits: Some international evidence. Journal of International Money and Finance, 19, 255-271.

Ravinthirakumaran, N., Selvanathan, S., \& Selvanathan, E. A. (2016). The twin deficits hypothesis in the SAARC countries: An empirical investigation. Journal of the Asia Pacific Economy, 21(1), 77-90.

Raza, S. A., \& Jawaid, S. T. (2014). Foreign capital inflows, economic growth and stock market capitalization in Asian countries: An ARDL bound testing approach. Quality \& Quantity, 48(1), 375385.

Rosensweig, J. A., \& Tallman, E. W. (1993). Fiscal policy and trade adjustment: Are the deficits really twins?. Economic Inquiry, 31(4), 580-594.

Saikkonen, P. (1992). Estimation and testing of cointegrated systems by an autoregressive approximation. Econometric Theory, 8(1), 1-27.

Saleh, A. S., Nair, M., \& Agalewatte, T. (2005). The twin deficits problem in Sri Lanka: An econometric analysis. South Asia Economic Journal, 6(2), 221239.

Salvatore, D. (2006). Twin deficits in the G-7 countries and global structural imbalances. Journal of Policy Modeling, 28, 701-712.

Şen, H., \& Kaya, A. (2016). Are the twin or triple deficits hypotheses applicable to post-communist countries?. BOFIT Discussion Papers, 3/2016.

Şen, A., Senturk, M., Sancar, C., \& Akbas, Y. E. (2014). Empirical findings on triplet deficits hypothesis: The case of Turkey. Journal of Economic Cooperation and Development, 35(1), 81-102.

Singh, T. (2015). Trade openness and economic growth in Canada: An evidence from time-series tests. Global Economy Journal, 15(3), 361-407.

Soukiazis E., Antunes, M., \& Kostakis, I. (2017). The Greek economy under the twin-deficit pressure: A demand orientated growth approach. International Review of Applied Economics, 32(2), 215-236.

Soukiazis, E., Cerqueira P. A., \& Antunes, M. (2015). Causes of the decline of economic growth in Italy with special reference to the post-euro period: A balance-of-payments approach. Review of Keynes- ian Economics, 3(4), 491-516.

Stock, J. H., \& Watson, M. W. (1993). A simple estimator of cointegrating vectors in higher order integrated systems. Econometrica, 61(4), 783-820.

Tang, C. F. (2015). General equilibrium perspective on twin deficits hypothesis: An empirical study with US results. Global Economic Review, 44(2), 184201.

Tang, C. F., \& Lean, H. H. (2007a). Will inflation increase crime rate? New Evidence from bounds and modified Wald tests. Global Crime, 8(4), 311-323.

Tang, C. F., \& Lean, H. H. (2007b). Is Phillips curve stable in Malaysia? New empirical evidence. $\mathrm{Ma}$ laysian Journal of Economic Studies, 44(2), 95-105.

Toda, H. Y., \& Yamamoto, T. (1995). Statistical inferences in vector auto-regressions with possibly integrated processes. Journal of Econometrics, 66(1), 225-250.

Tosun, M. U., Iyidogan, P. V., \& Telatar, E. (2014). The twin deficits in selected Central and Eastern European economies: Bounds testing approach with causality analysis. Romanian Journal of Economic Forecasting, XVII(2), 141-160.

Trachanas, E., \& Katrakilidis, C. (2013). The dynamic linkages of fiscal and current account deficits: New evidence from five highly indebted European countries accounting for regime shifts and asymmetries. Economic Modelling, 31, 502-510.

Ucal, H., \& Bolukbas, M. (2013). The role of twin deficits in sustainable growth: An econometric analysis for Turkey. Journal of Economic and Social Studies, 3(2), 39-51.

Vamvoukas, G. A. (1999). The twin deficits phenomenon: Evidence from Greece. Applied Economics, 31(9), 1093-1100.

Vlahinic, N., \& Jakovac, P. (2014). Revisiting the energy consumption-growth nexus for Croatia: New evidence from a multivariate framework analysis. Contemporary Economics, 8(4), 435-452.

Xie, Z., \& Chen, S-W. (2014). Untangling the causal relationship between government budget and current account deficits in OECD countries: Evidence from bootstrap panel Granger causality. International Review of Economics and Finance, 31, 95104.

Zapata, H. O., \& Rimbaldi, A. N. (1997). Monte Carlo evidence on cointegration and causation. Oxford Bulletin of Economics and Statistics, 59(2), 285298 